\title{
Influence of sheep breeds on feed intake, growth performance, digestibility and nitrogen utilization
}

\author{
A.M. El-Waziry ${ }^{1,2 *}$, G.M. Suliman ${ }^{1,3}$, A.N. Al-Owaimer ${ }^{1}$ \\ ${ }^{1}$ Department of Animal Production, College of Food and Agriculture Sciences, King \\ Saud University, P.O. Box 2460, 11451 Riyadh, Saudi Arabia \\ (owaimer100@yahoo.com) \\ ${ }^{2}$ Department of Animal and Fish Production, Faculty of Agriculture (El-Shatby), \\ Alexandria University, P.O. Box 21545, Alexandria, Egypt (aelwaziry@yahoo.com) \\ ${ }^{3}$ Department of Meat Production, Faculty of Animal Production, University of \\ Khartoum, Khartoum North Sudan (gsuliman@ksu.edu.sa) \\ *Correspondence: aelwaziry@yahoo.com \\ ORCID No. A.M. El-Waziry: https://orcid.org/0000-0003-3290-5296 \\ G.M. Suliman: https://orcid.org/0000-0001-9865-1589 \\ A.N. Al-Owaimer: https://orcid.org/0000-0003-4646-6124
}

\section{Simple Summary}

In Saudi Arabia, sheep are the majority of the livestock population, although it imported by large numbers to meet their people demands. The shortage between production and consumption in order to reduce the import proportions of sheep meat is our aim in this study through the evaluation effect of Saudi sheep breeds on feed intake, growth performance, digestibility and nitrogen utilization. Forty-five Saudi sheep breeds were used (namely Awassi, Harri, and Najdi). The sheep breeds had effect on the final live weight (FLW). Awassi breed recorded the highest FLW then Najdi and Harri, respectivley. The three group breeds had differ significantly on daily feed intake, daily gain and feed conversion ratio. For digestibility, the three breeds of had no effect in dry matter, organic matter, crude protein, crude fiber, nitrogen free extract, neutral detergent fiber, acid detergent fiber. In the same manner, no significant differences were founds among three groups of sheep in digestible organic matter, digestible of crude protein, total digestible nutrients and nitrogen retention.

\begin{abstract}
Forty-five of intact three sheep breeds (Awassi, Harri, and Najdi) were used in this study (15 animals of each breed), with weight ranged from 23.40 to $25.87 \mathrm{~kg}$. Five animals from each group at the end of growth trial were used for digestibility and nitrogen balance trials. The three groups of sheep had effect $(p>0.05)$ in the final live weight (FLW). Average daily feed intake (ADI), average daily gain (ADG) and feed conversion ratio (FCR) were significantly $(p<0.05)$ different among the three groups. For digestibility coefficients, the three breeds of sheep had no effect ( $p>$ $0.05)$ in dry matter $(\mathrm{DM})$, organic matter $(\mathrm{OM})$, crude protein $(\mathrm{CP})$, crude fiber $(\mathrm{CF})$, nitrogen free extract (NFE), neutral detergent fiber (NDF) and acid detergent fiber $(\mathrm{ADF})$. In the similar approach, no significant differences were founds among three
\end{abstract}


breeds of sheep in digestible organic matter, digestible of crude protein, total digestible nutrients and nitrogen retention. The current study concluded that the sheep breeds affected average daily feed intake, average daily gain and feed conversion ratio (FCR). Awassi breed showed the best of average daily gain and feed conversion ratio followed by Najdi then Harri breeds. The breed of sheep had no effect on digestibility coefficients and nitrogen retention.

\section{Keywords}

Sheep breeds, Awassi, Najdi, Harri, Growing, Digestibility, Nitrogen retention.

\section{Introduction}

Cattle, camels, sheep and goats are the livestock species to produce red meat in Saudi Arabia, and the populations of them are estimated to be 354276, 471704, 9055438 and 3563017 heads for cattle, camels, sheep and goats, respectively [1]. Therefore, the common of the livestock population is sheep (about 72\%), while the Saudi Arabia imports large amounts of sheep to meet their people demands [2]. The shortage between production and consumption in order to reduce the import proportions of sheep meat is our aims in this study. Firstly, for assessment is to evaluate the breed of sheep for their performance, production and the quality of their products. It is assumed that the performance of sheep as digestion, daily gain weight, growth [3-5] and carcass characteristics [6] can be different among sheep breeds. Furthermore, the information of performance for Awassi, Harri, and Najdi sheep is little, although these sheep breeds are the main breeds and favored by the citizens in Saudi Arabia comparison with the other breeds [6]. There are no enough recent studies comparing these breeds of sheep concerning their digestion, performance, carcass characteristics and meat quality; whereas, some of these breeds grown higher ranking in markets and among purchasers than the others lacking any really studies [6]. Hence, it is necessary to make comparison concerning these breeds to search their productively abilities. Therefore, the current study was conducted to investigate the effect of Saudi sheep breeds (Awassi, Harri and Najdi) on growth performance, digestibility coefficients, nutritive values and nitrogen utilization.

\section{Materials and Methods}

\subsection{Animals and Diets}

The condition of the present experiment was carried out as described by Suliman et al. [6]. Forty-five of intact three sheep breeds (Awassi, Harri, and Najdi) were used in this study (15 animals of each breed), with weight ranged from 23.40 to $25.87 \mathrm{~kg}$. Five animals from each group at the end of growth trial were used for digestibility and nitrogen balance trials. The experimental diet was formulated according to NRC [7]. The feed ingredients and chemical composition are shown in Table (1). The experimental diet and water and were offered to lambs ad libitum.

Table 1. Ingredients and chemical composition of experimental diet. 


\begin{tabular}{|c|c|}
\hline Item & DM basis, $\%$ \\
\hline \multicolumn{2}{|l|}{ Ingredients: } \\
\hline Alfalfa hay & 25.0 \\
\hline Maize & 39.3 \\
\hline Barley & 23.8 \\
\hline Soybean meal & 9.1 \\
\hline Mineral supplements ${ }^{\mathrm{a}}$ & 2.6 \\
\hline Trace mineral and vitamin premix ${ }^{b}$ & 0.2 \\
\hline \multicolumn{2}{|l|}{ Chemical composition: } \\
\hline $\mathrm{CP}$ & 13.50 \\
\hline $\mathrm{CF}$ & 8.16 \\
\hline $\mathrm{ADF}$ & 15.00 \\
\hline NDF & 49.42 \\
\hline NFE & 67.77 \\
\hline EE & 2.74 \\
\hline Ash & 8.60 \\
\hline $\mathrm{Ca}$ & 0.56 \\
\hline $\mathrm{P}$ & 0.29 \\
\hline $\mathrm{ME}, \mathrm{Mcal} / \mathrm{kg}^{\mathrm{c}}$ & 2.73 \\
\hline $\begin{array}{l}\text { aSupplements composition: } 30 \% \text { sodium bicarbonate; } \\
\text { dicalcium phosphate; } 20 \% \text { sodium chloride. }\end{array}$ & $30 \%$ ground limestone; $20 \%$ \\
\hline \multicolumn{2}{|c|}{$\begin{array}{l}\text { 'Contained per kg of mineral and vitamin premix: } \mathrm{CoSO} 4,0.30 \mathrm{~g} \text {; } \mathrm{CuSO} 4,20.1 \mathrm{~g} \text {; FeSO4, } \\
10.0 \mathrm{~g} \text {; } \mathrm{ZnO}, 50.0 \mathrm{~g} ; \mathrm{MnSO} 4,40.2 \mathrm{~g} \text {; } \mathrm{KI}, 0.75 \mathrm{~g} ; \mathrm{NaCl}, 2.81 \mathrm{~g} \text {; vitamin A, 500,000 IU; } \\
\text { vitamin } \mathrm{D}, 500,000 \mathrm{IU} \text { and vitamin E, 10,000 IU. }\end{array}$} \\
\hline
\end{tabular}

\subsection{Growth Performance Trials}

Forty-five intact males from the main Saudi sheep breeds were used as experimental units; namely Awassi, Harri, and Najdi. They were chosen as homogeneous as possible in their age. Then, they were distributed evenly into three groups of fifteen animals each in a complete randomized block design, where every block was contained three sub-blocks of five animals representing each breed. The feeding period was extend for 84 days, and during this period all the growth performance parameters were recorded. Lambs were weighed at the beginning and end of the experimental period to record initial live weight, final live weight, respectively. Animals were weighed weekly. Average daily gain, average daily feed intake and feed conversion ratio (FCR) were determined.

\subsection{Digestibility and Nitrogen Balance Trials}

At the end of growth trial, 5 animals from each group were used for digestibility and nitrogen balance trials. Animals were separated in individual pens. Then, the sheep were equipped for total fecal and urine collection. During the collection period (7-10 days), accurate records were kept for individual feed intake. Total fecal and urinary excretion were collected once a day. Sub samples (10\%) of feces and urine were taken once a day and stored at $-18^{\circ} \mathrm{C}$ for further analysis. 


\subsection{Chemical analysis}

Experimental diet and faces were analyzed according to AOAC [8] for dry matter $(\mathrm{DM})$, organic matter $(\mathrm{OM})$, crude protein $(\mathrm{CP})$, crude fiber $(\mathrm{CF})$, ether extract (EE) and ash. Nitrogen free extract (NFE) was calculated by differences as: NFE= [Dry Matter - $(\mathrm{CP}+\mathrm{EE}+\mathrm{CF}+\mathrm{Ash})]$. Nitrogen content was determined in urine by the method described by AOAC [8]. Neutral detergent fiber (NDF) and acid detergent fiber (ADF) were determined according to Van Soest et al. [9].

\subsection{Statistical Analysis}

The data were analysed using analysis of variance in SPSS ${ }^{\circledR}$ software program version 21, while separation of the means was presented using Duncan's Multiple Range Test [10]. The probability value, which expresses statistical significance, was $p$ $<0.05$.

\section{RESULTS AND DISCUSSION}

\subsection{Growth Performance Trials}

All animal started the experimental period of growth that extend for 84 days with mean average of initial live weight (ILW) about $24.56 \mathrm{~kg}$ (Table 2, Fig. 1). The ILW between the group animals did not differ significantly $(p>0.05)$. There were significant differences among the groups with the final live weight (FLW).The highest $(p<0.05)$ FLW was recorded with Awassi breed followed by Najdi then Harri (Table 2, Fig. 1). Average daily feed intake (ADI), average daily gain (ADG) and feed conversion ratio (FCR) were significantly $(p<0.05)$ different among the group breeds (Table 2). The Awassi sheep breed attained the highest $(p<0.05)$ ADI followed by Najdi and Harri, respectively. The best $(p<0.05)$ ADG and FCR was reported with Awassi sheep contrasted to the other two sheep breeds (Table 2), and this is in agreement with the report of Hassanin et al. [11]. The greater FLW of Awassi sheep is ascribed to ADG and FCR over Najdi and Harri breeds, where this is in agreement with the results of Aller et al. [12] and Kridi et al. [13]. The Harri breed had the lowest $(p<0.05)$ values of final weight, total gain, average daily feed intake, average daily gain during 84 days (Table 2) compared to Awassi and Najdi breeds and this was attributed to the less amount of DMI consumed by Harri breed [6]. The significant difference between Awassi and Najdi in final weight, total gain, average daily intake, and average daily gain during 84 days was not detected $(p>0.05)$, and this may due to the similar amount of average daily feed intake consumed by them [6]. Therefore, the best feed conversion ratio was recorded by Awassi followed by Najdi and Harri (Table 2). Conclusively, the discrepancies in FBW can be ascribed to the effect of the breed; besides effects of DMI and body fat. Several studies have indicated that breed is one of the primary factors affecting FBW [7,8, 14-18]. 
Table 2. Growth performance of the three breeds of sheep fed the experimental $\operatorname{diet}^{1}$.

\begin{tabular}{|c|c|c|c|c|c|}
\hline \multirow[b]{2}{*}{ Item } & \multicolumn{3}{|c|}{ Breeds $^{2}$} & \multirow[b]{2}{*}{$\mathrm{SEM}^{3}$} & \multirow[b]{2}{*}{$p>$} \\
\hline & AW & HA & NA & & \\
\hline Initial, kg & 24.31 & 24.70 & 24.68 & 0.215 & 0.7391 \\
\hline Final, kg & $50.52^{\mathrm{a}}$ & $44.51^{\mathrm{b}}$ & $48.54^{\mathrm{a}}$ & 0.863 & 0.0041 \\
\hline Total Gain, kg & $26.21^{\mathrm{a}}$ & $19.81^{\mathrm{b}}$ & $23.68^{\mathrm{a}}$ & 0.849 & 0.0009 \\
\hline Total Feeds, kg & $141.8^{\mathrm{a}}$ & $118.3^{\mathrm{b}}$ & $137.3^{\mathrm{a}}$ & 3.141 & 0.0002 \\
\hline \multicolumn{6}{|l|}{ Intake, $\mathrm{g}^{-\mathrm{d}}$} \\
\hline $0-28 d$ & $1402.4^{\mathrm{a}}$ & $1241.0^{\mathrm{b}}$ & $1363.1^{\mathrm{ba}}$ & 28.713 & 0.0425 \\
\hline $28-56 \mathrm{~d}$ & $1578.9^{\mathrm{a}}$ & $1233.7^{\mathrm{b}}$ & $1516.7^{\mathrm{a}}$ & 44.987 & $<0.0001$ \\
\hline $56-84 \mathrm{~d}$ & $2083.9^{\mathrm{a}}$ & $1749.4^{b}$ & $2025.2^{\mathrm{a}}$ & 26.68 & 0.0023 \\
\hline $0-84 \mathrm{~d}(\mathrm{ADI})^{4}$ & $1688.4^{\mathrm{a}}$ & $1408.0^{\mathrm{b}}$ & $1635.0^{\mathrm{a}}$ & 16.12 & 0.0443 \\
\hline \multicolumn{6}{|l|}{ Gain, $\mathrm{g}^{-\mathrm{d}}$} \\
\hline $0-28 d$ & 280.9 & 256.6 & 254.1 & 7.516 & 0.2941 \\
\hline $28-56 d$ & $320.9^{a}$ & $193.0^{\mathrm{b}}$ & $296.6^{\mathrm{a}}$ & 17.479 & 0.0005 \\
\hline $56-84 \mathrm{~d}$ & 334.2 & 257.9 & 301.2 & 17.423 & 0.2083 \\
\hline $0-84 \mathrm{~d}(\mathrm{ADG})^{4}$ & $312.0^{\mathrm{a}}$ & $235.8^{\mathrm{b}}$ & $284.0^{\mathrm{a}}$ & 10.108 & 0.0009 \\
\hline \multicolumn{6}{|l|}{ Intake: Gain } \\
\hline $0-28 d$ & 5.07 & 4.85 & 5.39 & 0.147 & 0.3497 \\
\hline $28-56 d$ & $4.98^{b}$ & $6.50^{\mathrm{a}}$ & $5.14^{b}$ & 0.240 & 0.0056 \\
\hline $56-84 d$ & 6.33 & 7.57 & 6.83 & 0.527 & 0.6581 \\
\hline $0-84 \mathrm{~d}(\mathrm{FCR})^{4}$ & $5.42^{\mathrm{b}}$ & $6.01^{\mathrm{a}}$ & $5.77^{\text {ba }}$ & 0.113 & 0.0955 \\
\hline
\end{tabular}

${ }^{1}$ Values represent means of 5 pens, 3 lambs each per treatment. Feeding period lasted 84 days.

${ }^{2}$ Breeds: $\mathrm{AW}=$ Awassi; $\mathrm{HA}=$ Harri; and $\mathrm{NA}=$ Najdi male lambs.

${ }^{3}$ Pooled standard error of means.

$4 \mathrm{ADI}=$ Average daily intake; $\mathrm{ADG}=$ Average daily gain; $\mathrm{FCR}=$ Feed conversion ratio.

$\mathrm{a}, \mathrm{b}$ Means within rows not sharing the same letter $(\mathrm{s})$ differ $(p<0.05)$. 


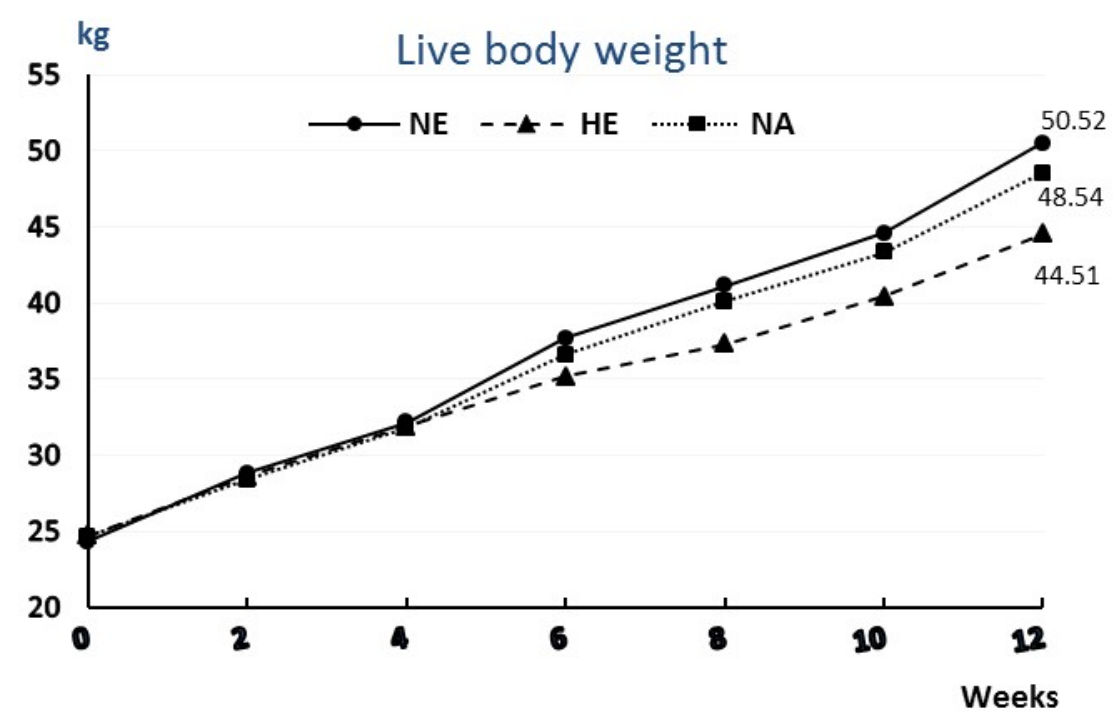

Fig 1. Effect of Experimental diet on live body weight of breeds lambs. Values are means $(n=15$ lambs/treatment). Breeds: $(\mathrm{NE}(\mathrm{AW})=$ Awassi; $\mathrm{HE}=$ Heri; $\mathrm{NA}=$ Najdi male lambs).

Pooled standard error of means at d0, 14, 28, 42, 56, 70 and 84 were 0.22 , $0.23,0.26,0.42,0.55,0.58$ and 0.86 , respectively.

\subsection{Digestibility and Nitrogen Balance Trials}

Dry matter intake, digestibility coefficients and nutritive values of the experimental diet fed to the three breeds of sheep are presented in Table (3). There was significant $(p<0.05)$ difference between Harri breed compared to Awassi and Najdi breeds in dry matter intake (DMI). The lowest value of DMI was recorded with Harri followed by Najdi and Awassi, and the values were 1186.3, 1783.7 and 1808.9 $\mathrm{g} /$ day for Harri, Najdi and Awassi, respectively. There was no significant $(p>0.05)$ difference between Najdi and Awassi in DMI. These results were parallel with the results of DMI in the growing trail in the present study. 
Table 3. Dry matter intake, digestibility coefficients and nutritive values of the experimental diet fed to the three breeds of sheep ${ }^{1}$.

\begin{tabular}{|c|c|c|c|c|c|}
\hline \multirow[b]{2}{*}{ Item } & \multicolumn{3}{|c|}{ Breeds $^{2}$} & \multirow[b]{2}{*}{$\mathrm{SEM}^{3}$} & \multirow[b]{2}{*}{$p>$} \\
\hline & AW & HA & NA & & \\
\hline Dry matter intake (DMI,g/day) & $1808.9^{\mathrm{a}}$ & $1186.3^{\mathrm{b}}$ & $1783.7^{\mathrm{a}}$ & 92.36 & $<0.0001$ \\
\hline \multicolumn{6}{|l|}{ Digestibility coefficients (\%): } \\
\hline Dry matter (DM) & 61.61 & 64.69 & 60.87 & 0.952 & 0.2359 \\
\hline Organic matter $(\mathrm{OM})$ & 65.81 & 69.10 & 65.19 & 0.919 & 0.1796 \\
\hline Crude protein $(\mathrm{CP})$ & 53.30 & 56.22 & 52.42 & 1.280 & 0.4911 \\
\hline Ether extract (EE) & $86.13^{b}$ & $89.97^{\mathrm{a}}$ & $88.52^{\text {ba }}$ & 0.679 & 0.0569 \\
\hline Crude fiber (CF) & 44.28 & 46.52 & 40.16 & 1.704 & 0.3321 \\
\hline Nitrogen free extract (NFE) & 73.30 & 76.93 & 73.51 & 0.860 & 0.1530 \\
\hline Neutral detergent fiber (NDF) & 57.02 & 60.79 & 54.65 & 1.437 & 0.2261 \\
\hline Acid detergent fiber (ADF) & 43.38 & 47.04 & 41.66 & 1.585 & 0.4051 \\
\hline \multicolumn{6}{|l|}{ Nutritive value (\%): } \\
\hline Digestible OM (DOM) & 58.92 & 61.86 & 58.36 & 0.823 & 0.1796 \\
\hline Digestible CP (DCP) & 7.05 & 7.44 & 6.94 & 0.170 & 0.4911 \\
\hline Total digestible nutrients (TDN) & 63.02 & 66.15 & 62.58 & 0.835 & 0.1665 \\
\hline
\end{tabular}

${ }^{1}$ Values represent means of 4 lambs / treatment;

${ }^{2}$ Breeds: $\mathrm{AW}=$ Awassi; $\mathrm{HA}=$ Harri; and $\mathrm{NA}=$ Najdi male lambs.

${ }^{3}$ Pooled standard error of means.

a, b Means within rows not sharing the same letter (s) differ $(p<0.05)$.

For digestibility coefficients, there were no significant $(p>0.05)$ differences among the three breeds of sheep in dry matter (DM), organic matter (OM), crude protein $(\mathrm{CP})$, crude fiber $(\mathrm{CF})$, nitrogen free extract (NFE), neutral detergent fiber (NDF) and acid detergent fiber (ADF) (Table 3). The three breeds of sheep had no effect $(p>0.05)$ in digestible organic matter (DOM), digestible of crude protein (DCP) and total digestible nutrients (TDN). The present results indicated that the larger DMI depresses the nutrient digestibility and this is in agreement with NRC [19]. Potts et al. [20] reported that greater intake depresses nutrient digestibility and can expect that residuals feed intake will be negatively correlated with digestibility. A major factor influencing nutrient utilization in dairy cattle is the relationship between feed intake and diet digestibility [21]. Therefore, Harri sheep breed affected 
numerically DMI and hence the nutrient digestibility and this is in agreement with NRC [19-21].

Nitrogen utilization of three breeds of sheep fed the experimental diet is shown in Table (4). The lowest value of nitrogen intake was recorded $(p<0.05)$ with Harri breed compared to other two breeds; this is attributed to the less amount of DMI consumed by animals. There was no significant $(p>0.05)$ difference between Awassi and Najdi in nitrogen intake. There was no significant $(p>0.05)$ difference in nitrogen retention among the three breeds, although Harri breed had the low value of nitrogen intake as mentioned, this due to the lowest value which excreted nitrogen in fecal by Harri breed compared to Awassi and Najdi breeds (Table 4).

Table 4. Nitrogen $(\mathrm{N})$ utilization of the three breeds of sheep fed the experimental $\operatorname{diet}^{1}$.

\begin{tabular}{|c|c|c|c|c|c|}
\hline \multirow[b]{2}{*}{ Item } & \multicolumn{3}{|c|}{ Breeds $^{2}$} & \multirow[b]{2}{*}{ SEM $^{3}$} & \multirow[b]{2}{*}{$p>$} \\
\hline & $\mathrm{AW}$ & HA & NA & & \\
\hline \multicolumn{6}{|l|}{ Nitrogen balance } \\
\hline $\mathrm{N}$ intake $\mathrm{g}^{-\mathrm{d}}$ & $38.29^{\mathrm{a}}$ & $25.11^{\mathrm{b}}$ & $37.76^{\mathrm{a}}$ & 1.955 & $<0.0001$ \\
\hline \multicolumn{6}{|l|}{$\mathrm{N}$ excretion: } \\
\hline Fecal g-d & $17.84^{\mathrm{a}}$ & $11.04^{\mathrm{b}}$ & $17.94^{\mathrm{a}}$ & 1.107 & 0.0013 \\
\hline Urinary $\mathrm{g}^{-\mathrm{d}}$ & 12.47 & 8.46 & 11.84 & 0.873 & 0.1252 \\
\hline Absorbed $\mathrm{N} \mathrm{g}^{-\mathrm{d}}$ & $20.45^{\mathrm{a}}$ & $14.07^{\mathrm{b}}$ & $19.82^{\mathrm{a}}$ & 1.005 & 0.0023 \\
\hline \multicolumn{6}{|l|}{$\mathrm{N}$ retention: } \\
\hline $\mathrm{g}^{-\mathrm{d}}$ & 7.98 & 5.61 & 7.98 & 1.039 & 0.6065 \\
\hline$\%$, of $\mathrm{N}$ intake & 20.77 & 21.66 & 21.14 & 2.942 & 0.9939 \\
\hline$\%$, of absorbed $\mathrm{N}$ & 37.79 & 37.99 & 40.19 & 4.991 & 0.9808 \\
\hline
\end{tabular}

\section{Conclusion}

The present study concluded that the sheep breed affected average daily feed intake, average daily gain and feed conversion ratio. Awassi breed showed the best of average daily gain and feed conversion ratio followed by Najdi and Harri 
breeds. Harri breed had the lowest average daily gain and feed conversion. The breed of sheep had no effect on digestibility coefficients and nitrogen retention although Harri sheep breed affected numerically dry matter intake and hence the nutrient digestibility nitrogen retention. Therefore, more studies will be needed to achieve for evaluating the three sheep breeds under study considering their performance, carcass characteristics and meat quality to confirm which of them gain higher standing among consumers.

Authors Contributions: A.M. El-Waziry and G.M. Suliman: conceptualization. A.M. El-Waziry and A.N. Al-Owaimer: methodology. A.M. El-Waziry: software. A.M. El-Waziry and G.M. Suliman: investigation. A.M. El-Waziry and G.M. Suliman: data curation. A.M. El-Waziry and G.M. Suliman: writing - original draft preparation, review and editing. A.N. Al-Owaimer: visualization. The authors have read and agreed to publish the version of the manuscript.

Funding: This work was funded by King Abdulaziz City for Science and Technology (KACST) in Saudi Arabia through the Research Grant No.: LGP 35-44.

Institutional Review Board Statement: The King Saud University committee reviewed and approved to use the animals of this study (Ethics Reference No: KSUSE-20-17).

Data availability statement: The data of current study are available on request from the authors.

Acknowledgments: The authors would like to acknowledge King Abdulaziz City for Science and Technology (KACST) for supporting this study (Research Grant No.: LGP 35-44).

Conflicts of Interest: The authors declare no competing financial interest.

\section{References}

1. GASTAT. Agriculture, water and environment. In: General Authority for New World Camelids; Washington, DC: The National Academies Press Statistics. Statistical Yearbook of 2018. Available online at: https:// www.stats.gov.sa/en/1011 (accessed March 3, 2021).

2. BMI. The Business Monitor International, Food and Drink Report on Saudi Arabia,http://www.researchandmarkets.com/reports/2364081/saudi_arabia_food_a nd_drink_report_q1_2013.

3. Samara, E.M.; Okab, A.B.; Abdoun, K.A.; El-Waziry, A.M.; Al-Haidary, A.A. The subsequent influences of feeding intact green seaweed Ulva lactuca to growing 
lambs on the seminal and testicular characteristics in rams. J. Anim. Sci. 2013, 91, 5654-5667.

4. Abdoun, K.A.; Okab, A.B.; El-Waziry, A.M.; Samara, E.M.; Al-Haidary, A.A. Dietary Supplementation of Seaweed (Ulva lactuca) to alleviate the Impact of Heat Stress in Growing Lambs. Pak. Vet. J. 2014, 34, 108-111.

5. El-Waziry, A.M.; Al-Haidary, A.A.; Okab, A.B.; Samara, E.M.; Abdoun, K.A. Effect of dietary seaweed (Ulva lactuca) supplementation on growth performance of sheep and on in vitro gas production kinetics. Turk. J. Vet. Anim. Sci. 2015, 39, 81-86.

6. Suliman, G.M.; Al-Owaimer, A.N.; El-Waziry, A.M.; Hussein, E.O.S.; Abuelfatah, K.; Swelum, A.A. A Comparative Study of Sheep Breeds: Fattening Performances, Carcass Characteristics, Meat Chemical Composition and Quality Attributes. Front. Vet. Sci. 2021, 8, 647192.

7. NRC. Nutrient Requirements of Small Ruminants: Sheep, Goats, Cervids, and NewWorld Camelids;Washington,DC: The National Academies Press, 2007, 384.

8. AOAC. Official methods of analysis. In: Herlick K, et al., editors. Association of Official Analytical Chemists. $16^{\text {th }}$ ed. 2007, Arlington, VA.

9. Van Soest, P.J.; Robertson, T.B., Lewis, B.A. Methods for dietary fiber, neutral detergent fiber and non-starch polysaccharides in relation to animal nutrition. $J$. Dairy Sci. 1991, 74, 3583-3597.

10. Duncan, D.B. Multiple ranges and multiple F test. Biometrics, 1955, 11, 1-15.

11. Hassanin, S.H; Hussein, A.F.; Khattab, Y.A.; Abdalla, M.A. Reproductive performance of rams under arid conditions. Life Sci. J. 2013, 10: 2546-2606.

12. Aller, J.F.; Aguilar, D.; Vera, T.; Almeida, G.P.; Alberio, R.H. Seasonal variation in sexual behavior, plasma testosterone and semen characteristics of Argentine Pampinta and Corriedale rams. Spanish J. Agri. Res. 2012, 10, 345-352

13. Kridi, R.T.; Abdullah, A.Y.; Shaker, M.M.; Al-Momani, A.Q. Age at puberty and some biological parameters of Awassi and its first crosses with Charollais and Romany rams. Italian J. Anim. Sci. 2006, 5, 193-202.

14. BMIIR. Business Monitor International - Industry Reports. Saudi Arabia Food and Drink Report Aug 27, 2016. New York, NY: Alacra Store. Retrieved from: http://www.alacrastore.com/storecontent/Business-Monitor-International Industry, Reports/Saudi-Arabia-Food-and-Drink-Report-2026-454 (accessed March 03, 2021). 
15. Al-Owaimer, A.N.; Suliman, G.M.; Sami, A.S.; Picard, B.; Hocquette, J.F. Chemical composition and structural characteristics of Arabian camel (Camelus dromedarius) m. longissimus thoracis. Meat Sci. 2014, 96, 1233-41.

16. Wilhelm, A.E.; Maganhini, M.B.; Hernández-Blazquez, F.J.; Ida, E.I.; Shimokomaki, M. Protease activity and the ultrastructure of broiler chicken PSE (pale, soft, exudative) meat. Food Chem. 2010, 119, 1201-4.

17. Culler, R.D.; Parrish, F.C Jr.; Smith, G.C.; Cross, H.R. Relationship of myofibril fragmentation index to certain chemical, physical and sensory characteristics of bovine longissimus muscle. J Food Sci. 1978, 43, 1177-80.

18. Ayele, S.; Urge, M.; Animut, G.; Yusuf, M.J. Comparative slaughter performance and carcass quality of three Ethiopian fat-tailed hair sheep breeds supplemented with two levels of concentrate. Trop Anim Health Prod. 2019, 51, 187-98.

19. NRC. National Research Council. Nutrient Requirements of Dairy Cattle. $7^{\text {th }}$ ed. 2001, Natl. Acad. Press, Washington, DC.

20. Potts, S.B.; Boerman, J.P.; Lock, A.L.; Allen, M.S.; VandeHaar, M.J. Relationship between residual feed intake and digestibility for lactating Holstein cows fed high and low starch diets. J. Dairy Sci. 2017, 100, 265-278.

21. Colucci, P.E.; Chase, L.E.; Van Soest, P.J. Feed Intake, Apparent Diet Digestibility, and Rate of Particulate Passage in Dairy Cattle. J. Dairy Sci. $1982,65,1445-1456$. 